\title{
4.0 For Agriculture
}

\author{
M.Atilla Arıcıoğlu, Aylin Yılmaz, and Nadiye Gülnar
}

\begin{abstract}
Recently, there was a struggle to control the volume of production and the volume of production between countries and regions in the world. Rather, western countries had a desire to attract investments in the east to their own countries and regions. This desire has led to the emergence of the Industry 4.0 phenomenon of the West, which is Germany. In other words, with this phenomenon, the industry is aimed to digitize production more and contribute to the issues of speed, efficiency and flexibility by providing digitalization in production. With these changes, Industry 4.0, was seen that the system was working better than it was and production was made cheaper than the system, when taking the muscle strength out of the system. While the positive contributions of Industry 4.0 have resonated with all sectors, it has also started to have an impact on the agricultural sector. Problems such as scarcity in the world, not using natural resources effectively and not using technology in the agricultural field, have caused the emergence of digitalization in the agricultural sector. "Agriculture 4.0", wich means making smart production with smart farming practices by using the concepts, information and technologies in the literature. In line with the possibilities and technological developments offered by Industry 4.0, it enables the sensors to be seen in all agricultural machines from the tractor to the crop tools and the communication of the machines in the entire production process by entering the internet of things into the agricultural sector. As a matter of fact, with the agriculture 4.0, the traditional agriculture paradigm has not been sufficient anymore and it contributes to sustainability, to be productive, to protect the rural texture, to protect the environmental quality and to provide accessible food by undergoing changes and agricultural practices. In the study, the problems experienced in the agricultural sector, the effects of Agriculture 4.0 on these problems and how they will benefit are discussed. The use of technology has given the system its name and agriculture has also taken its share in the developments. Accordingly, what are the practices of Agriculture 4.0 in the world and how their contributions are investigated.
\end{abstract}

Index Terms-Agriculture, 4.0, Digital Revolution

\section{INTRODUCTION}

Since nutrition chain and agriculture is a basic and indispensable issue for humanity, its place in the world is also important. It is also considered as one of the critical issues facing humanity in the production, transportation, storage and distribution of food. However, it is known that agricultural production is under great pressure due to both increasing population and important changes in climate [36]. In the UN's 2015 report of "Transforming Our World" for

Published on June 24, 2020

M.Atilla Arıcıoğlu, Necmettin Erbakan University, Faculty of Political Sciences, Business Administration, Turkey.

(corresponding email: maaricioglu@gmail.com)

Aylin Yılmaz, Karamanoğlu Mehmet Bey University, Vocational Schools of Social Sciences, Turkey.

(e-mail: aylinyilmaz@kmu.edu.tr) sustainable development, it points out that approximately 800 million people in the world experienced hunger problems and by $2030,8 \%$ of the world will experience problems caused by malnutrition. In the United Nations report, he emphasized that $\$ 265$ billion should be invested in the agricultural sector to prevent hunger and deal with poverty [54]. On the other hand, the United Nations Food and Agriculture Organization (FAO) needs to increase $70 \%$ of food production by 2050 in order to keep up with the increase in the world population . [17]. In addition, how to ensure climate stability necessary for agricultural sustainability is discussed through greenhouse gas. It is possible to intervene in climate change by reducing the world greenhouse gas, with less fertilizer and less water use techniques and it is stated that it will be possible to produce $70 \%$ more food until 2050 [5].

In this context, poverty and the inefficient use of natural resources provide significant opportunities for innovations that may occur in the agricultural sector. Because agriculture is affected by many factors, including economic conditions, technological developments and environmental constraints, and these situations cause paradigm changes. The traditional agricultural paradigm largely emphasizes productivity. However, agriculture exists not only to increase production and productivity, but also to protect resources and the environment [6]. On the other hand, as it is known, negativities such as global warming, climate change, drought decrease efficiency and productivity in agriculture. For this reason, agricultural practices and research; agriculture that will ensure sustainability, be productive, protect the texture and environmental quality of rural society, provide economic / social gains to individuals and firms in the production system, provide a holistic economic development, increase social welfare, and ultimately provide a crop yield and an accessible food source. sector is targeted [20], [31]. From the perspective of economic inequality or distribution, this target appears to be even more important for the underdeveloped countries. Increasing the growth potential of underdeveloped countries and reducing poverty can be achieved through sustainable agriculture. In other words, countries in Africa, unlike Asian countries, must realize a broad-based agricultural revolution in order for the economic transformations to take place successfully [12]. It is possible to understand what agricultural development means for the sustainability of the expected revolution and the historical

Nadiye Gülnar, Konya Food and Agriculturel University, Turkey. (e-mail: Nadiye.Gulnar@gidatarim.edu.tr). 
process by removing the obstacles to agriculture, not only in Africa but in a global world.

In order for the process to be better understood, if the negativities experienced in the agricultural sector are generally classified under three headings, these are; The famine of the world is not using the natural resources effectively and not using the technology correctly in the agricultural field [35]; [12]; [11]. These problems are social such as inequality and distribution inequality, technical and structural problems such as efficiency and effectiveness that determine this and these problems need to be solved. In other words, the use of technology and technology should give the system its name, and agriculture should take its share from the revolution in a significant way within the framework of the developments. For this, it is important to define the response of industry 4.0 in the agricultural field and to handle the process with a correct expression. Because, in line with the possibilities and technological developments offered by Industry 4.0, it enables the sensors to be seen in all agricultural machines from the tractor to the crop tools and the communication of the machines during the entire production process by entering the internet of objects into the agricultural sector. With agricultural machinery and agricultural fields equipped with digital sensors, it is seen that the farmer facilitates the work of the farmer by providing opportunities such as how much fertilizer is given to which areas, weather conditions, what minerals the plants need, irrigation, soil condition, estimated harvest time. Using the new techniques brought by technology in the agricultural sector, the production of different products, increasing the efficiency in the food chain, bringing food production to consumers and using technology are promising in terms of sustainability and solution of problems.

\section{The Meaning of Agriculture for the World}

The world's number of population given in 2020 is about 7.5 billion. When the population distribution in the world is analyzed, it is seen that China has the most population [64]. China takes the first place with a population of about 1.5 million, then in the second place is India with a population of about 1.4 million, and the USA is ranked with approximately 350 million, Indonesia with approximately 270 million. Approximately $10 \%$ of the world population also struggles with poverty. Because the growing population and the increase in the production of agriculture do not proceed in equidistant [55].

When we look at 2019 agricultural production area in the world, 36,81 million hecrates have been planted. 72,61 million metric tons of production was obtained from this area. It contributed to the agricultural sector with 7,00 million hecrates production in the European Union region, Canada 9,00 million hecrates production and China with 6,15 million hecrates area. Europe Union produced 20,06 million metric tons, Canada 20,01 million metric tons and China 13,28 million metric tons [18].

The contribution of agriculture to economic production in the world has been determined as 6.4 percent. The total production of the sector is $\$ 5,084,800$ million [61].

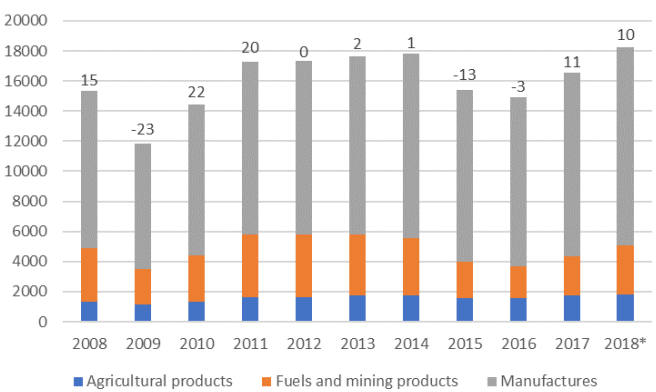

Fig. 1: Share Graph of Agricultural Production in the World Economy [62]

Countries with the largest economy in the world; US (\$ 20,412,870 million), China (\$ 14,092,514 million), Japan (\$ $5,167,051$ million) and Germany (\$4,211,635 million). In the ranking of agricultural income in the world, it is seen that China (13.608.2 \$ billions), India (2.726.3 \$ billions), Israel 369.7 \$ billions, Netherlands $913.7 \$$ billions [62].

China and India account for 19.49 and 7.39 percent of total global agricultural production. The world's largest economy, the United States, ranks third, followed by Brazil and Indonesia(https://www.statisticstimes.com/economy/countri es-by-gdp-sector-composition.php). While the agricultural sector is an important source of employment in some countries, it provides input to the industrial sector, creating demand for industrial products and contributing to total exports through the export of agricultural products. For example, $70 \%$ of the population in India provides a livelihood from agriculture and agriculture contributes to only $18 \%$ of GDP. It is stated that the main reason for this low performance is that automation is not used sufficiently in agricultural production [14]. When evaluations are made on the basis of countries in the agricultural sector, developing countries and developed countries also differ. Agriculture has a lower share in GDP in developed countries, but developing countries also make less but more stable progress in GDP [2]. The reason for this is that agricultural production may be the only industry of the current industry in developing countries [35].

\section{OVER INDUSTRY 4.0}

Many variable variables such as the speed of economic and commercial changes in the world, increasing population and instability of resource constraints, sustainability pressure, technological changes, climate change, urbanization, political interactions, demographic change and diversified customer expectations have affected the formation of industrial revolutions. Due to these factors, innovations in the industry cause revolutions and paradigm shifts in the same way [41]. While Industry 4.0, the new name for this change, proposes a new paradigm shift, discussions and definitions are continuing. The main direction characterized by Industry 4.0, which was announced at the Hannover fair in 2011 in Germany, is referred to as the smart production application [43], [37]. Robots of $75 \%$ of the Amberg factory of Siemens in the city of Germany have robots, while the remaining $25 \%$ have employees who are engaged in corporate affairs. The factory, which has over a thousand product types, produces over a million and its margin of error is very low [45]. A factory on telephone manufacturing in Dongguan, China is 
known as the world's first unmanned robot factory. While $80 \%$ of the factory is robots, $20 \%$ is technical team. A robotic arm can do the work that an average of 68 workers take on. In other words, it has positive results in terms of employees, time and productivity [52]. With Industry 4.0, it reorganized its understanding of production and marketing focused on speed, efficiency, cost and innovation [46].

Industry 4.0 , which is based on the integration of information, communication and industrial technologies, establishes a flexible production model through cyberphysical systems and interacts in real time with people, objects and products [65]. Industry 4.0 is also defined as the integration of the value chain with modern technologies. Within the framework of these definitions, within the basic components of Industry 4.0; cyber physical systems, internet of things, 3D printers (additive manufacturing), cloud computing, big data, artificial intelligence, vertical and horizontal integration, cyber security, augmented reality and simulation [60]; [48]; [40]; [21].It is the robots that take the most active role in Industry 4.0 [41]. Because they play an active role in autonomous decision making and cooperation between units [60]. The Internet of Things is the ability to collect, increase and organize data from different sources. The Internet of Things allows for disconnected data management that speeds up process audits and enables data to be transformed into information that will take action on the cyber-physical system [27]. Big data that plays a remarkable role in the correct management of the whole process; These are clusters of data that cannot be achieved with typical database software, which are methods of capturing, storing, managing and analyzing data [33]. Cloud, which is another actor, has five characteristics: self-service, wide network access, resource pool, fast elasticity and measurable service possibilities. It has important benefits such as mediation [7]. Cyber-physical systems that provide access to data and data processing services over the internet for Industry 4.0, and systems that are in connection with the physical world and processes are Cyber Physical Systems [34]. Process; In the virtual world, operators will be able to interact with their machines and change their parameters by clicking a cyber button. It will be possible to receive operational data and maintenance instructions. Due to these advantages; companies will use Augmented Reality to improve decision making and business procedures [42]. Thus, in real systems, simulation tools are needed to monitor the positive / negative effects of this change before changing certain parameters and variables on the system. The agility of the system can be monitored against changing situations [4]. All this raises integration for 4.0. Collaboration of many businesses with a communication network is called Horizontal Integration. Vertical integration, on the other hand, is to increase the information exchange of enterprises and to cooperate between different hierarchical levels [8]. 3D printers, which are expected to further affect this revolution and the working process, flatten production and cause the emergence of new types of business oriented individuals, are the infrastructure of the revolution and the paradigm of the new economy. 3D emphasizes horizontal power among individuals rather than hierarchical force. With additive manufacturing, there is a shift towards the concept of urea / consumer instead of consumer [39]. Ultimately, the security of this virtual and eclectic structure is ensured by cyber security. Cyber security; It is the technological system that allows the machines to work in integration with each other and allow information exchange to be carried out safely [4]. These technological developments provide the basis for the implementation of new production processes and business models called smart systems [30]. Thanks to the digital connectivity offered by Industry 4.0, integration in all functions of the business is provided. This provides convenience in increasing the efficiency of the enterprises, providing flexibility in production, reducing costs, providing increased customer satisfaction, ensuring the traceability of the system and facilitating the detection of failures, and ensuring a sustainable operation with environmentally friendly and resource saving behavior. Industry 4.0 also reduces production, logistics and management costs, which are among the operational functions, by up to $30 \%$ and brings improvements in these functions [3].

\section{Why AND How FOR Agriculture 4.0}

Innovations in the field of agriculture must meet the real needs of the consumers and continue their activities by maximizing the technology. Thus, developments experienced increase the adequacy and efficiency of agricultural activities. Therefore, it is necessary to first understand what agricultural activities are and how agriculture works so that it will be easier to determine what will be the future innovations in the field of agriculture or what the deficiencies are in the field of agriculture [14].

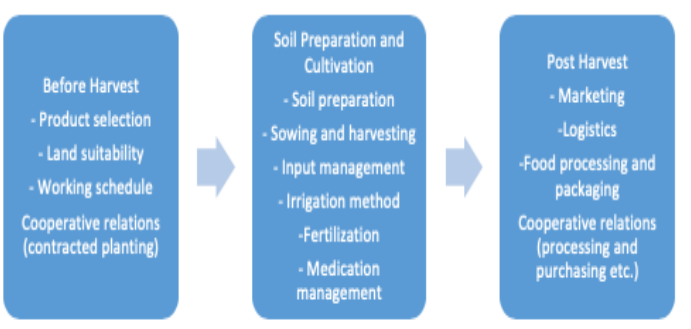

Fig. 2. Agricultural Activity Processes [19]

In this process, the activities performed before the harvest are presented first. Things to be done before harvest; there are possibilities to choose the right crop seedlings, the suitability and selection of the land, information on when to produce, and to cooperate with cooperatives. The pre-harvest step is the stage that determines the productivity in agriculture. Then the second step is soil preparation and planting. What are the activities that facilitate the works in preparing the soil during production, during planting, irrigation, fertilizing and spraying, and what is considered in these stages. The last stage is post-harvest activities, these include marketing of the product, logistics service of the product, processing and packaging of the product. This process is also mentioned in the literature as farmer decision support systems [19]. It also shows the disruptions in the operation of agriculture that 
occur during the stages of agricultural activity. There are many factors that decrease productivity in agriculture and these factors vary. $35-40 \%$ of the foods produced in agriculture are not consumed by consumers and this is recorded as food losses [51]. Improper land use in agriculture, increases in energy, water and fertilizer consumption are among other important factors that decrease productivity in agriculture [16]. Climate change affects the continuity of water resources [59] and the safety of food, because production timings are also changing [29]. Global warming and climate changes have also changed the course of using energy resources, so that not using resources properly has reduced productivity in agriculture. In order to eliminate the factors that reduce inefficiency in the agricultural sector, innovations are taken in the field of agriculture [32]. The aim of the world is to increase productivity in agriculture, which is possible by increasing productivity in agriculture. The way to increase efficiency is by integrating technology with agriculture. The digitization of agriculture eliminates most events that reduce productivity. For this reason, the realization process of agriculture should first be considered [14].

With the application of Industry 4.0 in agriculture, there are many innovations and these innovations also provide new perspectives in the agricultural sector. The issue that has been discussed recently is the digitalization of agriculture. Digitalization in agriculture is not an instant developing event, it has emerged after a certain period of time. As it is known, the first production activities in the field of agriculture were carried out by humans and animals, and then mechanizations played a role when electricity came to life. With the innovations brought by computer and automation systems, developments in greenhouse and irrigation automations, and innovations in information and technologies have caused the emergence of the "smart farming" phenomenon [14]. This system, which is called "Smart Agriculture" Precision Agriculture or Agriculture 4.0 in most sources, is becoming more and more widespread every day [1]. "Big Data" has a significant importance in agriculture as well as in industry [56].

With the rapid progression of the internet of things and cloud processing [63]; [44], digital agriculture defines as an extension of the concept of the "Digital World" proposed in the 90s and emphasizes the production method in the "Sensitive Agriculture" process. However, prevalence and pace are slower than industry. Especially land, open air, climatic conditions and a complex level of relationship in the process explain this slowness. According to the research conducted at McKinsey Global Institute, agriculture sector is seen as the sector with the lowest digital transformation compared to other sectors. However, the way to increase production and increase productivity in agriculture is through the integration of agriculture with technology [33]. Digital agriculture, also known as knowledge-based agriculture model, places and advances the processing and interpretation of digital data based on agricultural production and management systems [28]. It focuses on the agricultural production process and emphasizes rational connections in the process. This helps to take into account local, spatial, environmental heterogeneities and global climate phenomena, as well as making informed decision making, social demands as well as satisfying individual producer and consumer needs in terms of efficiency and profit [61]. Agriculture 4.0 is aimed to increase productivity in agriculture to the highest levels with smart farming practices using information and communication technologies. As a matter of fact, Agriculture 4.0 guides agriculture through the Global Positioning System (GPS) and provides convenience in monitoring and controlling agricultural areas. It is possible to discuss how this should be handled as a whole and the studies / literature on agriculture related fields together structure as follows:

Table 1. Benefits of Smart Agriculture [63]

\begin{tabular}{|c|c|c|}
\hline $\begin{array}{c}\text { Smart Agriculture } \\
\text { Cycle }\end{array}$ & Arable Land & Livestock \\
\hline $\begin{array}{l}\text { Intelligent detection } \\
\text { and monitoring }\end{array}$ & $\begin{array}{l}\text { Robot technologies } \\
\text { and sensors (Faulkner } \\
\text { and Cebul, 2014) }\end{array}$ & $\begin{array}{l}\text { Biometric detection, } \\
\text { GPS tracking (Sonka, } \\
2014 \text { ) }\end{array}$ \\
\hline $\begin{array}{l}\text { Intelligent analysis } \\
\text { and planning }\end{array}$ & $\begin{array}{l}\text { Seeding, planting, soil } \\
\text { structure, } \\
\text { phytosanitary, yield } \\
\text { modeling (Noyes, } \\
2014 \text { ) }\end{array}$ & $\begin{array}{l}\text { Breeding, monitoring } \\
\text { (Cole et al., 2010) } 9\end{array}$ \\
\hline Intelligent control & $\begin{array}{l}\text { Sensitive agriculture } \\
\text { (Sun et al., 2013b) }\end{array}$ & $\begin{array}{l}\text { Dairy robots } \\
\text { (Grobart, } 2012\end{array}$ \\
\hline Big data in the cloud & $\begin{array}{l}\text { Weather / climate } \\
\text { data, yield data, soil } \\
\text { types, market } \\
\text { information, } \\
\text { agricultural census } \\
\text { data (Chen et al., } \\
\text { 2014) }\end{array}$ & $\begin{array}{l}\text { Live animal } \\
\text { movements (Faulkner } \\
\text { and Cebul, 2014) }\end{array}$ \\
\hline $\begin{array}{c}\text { Smart Agriculture } \\
\text { Cycle }\end{array}$ & Horticulture & Fishery \\
\hline $\begin{array}{l}\text { Intelligent detection } \\
\text { and monitoring }\end{array}$ & $\begin{array}{l}\text { Robot technologies } \\
\text { and sensors } \\
\text { (temperature, } \\
\text { humidity, CO2 etc.), } \\
\text { greenhouse computers } \\
\text { (Sun et al., 2013a) }\end{array}$ & $\begin{array}{l}\text { Automatic } \\
\text { identification systems } \\
\text { (AIS) (Natale et al., } \\
\text { 2015) }\end{array}$ \\
\hline $\begin{array}{l}\text { Intelligent analysis } \\
\text { and planning }\end{array}$ & $\begin{array}{l}\text { Lighting, energy } \\
\text { management (Li and } \\
\text { Wang, 2016) }\end{array}$ & $\begin{array}{l}\text { Surveillance and } \\
\text { monitoring (Yan et } \\
\text { al., 2013) }\end{array}$ \\
\hline Intelligent control & $\begin{array}{l}\text { Climate control, } \\
\text { precise control (Luo } \\
\text { et al., 2012) }\end{array}$ & $\begin{array}{l}\text { Surveillance and } \\
\text { monitoring (Yan et } \\
\text { al., 2013) }\end{array}$ \\
\hline Big data in the cloud & $\begin{array}{l}\text { Weather / climate, } \\
\text { market information, } \\
\text { social media } \\
\text { (Verdouw et al., } \\
2013 \text { ) }\end{array}$ & $\begin{array}{l}\text { Market data (Yan et } \\
\text { al., 2013), satellite } \\
\text { data (European Space } \\
\text { Agency, 2016) }\end{array}$ \\
\hline
\end{tabular}

As seen from an inclusive perspective, Agriculture 4.0 has an extensive interaction network. In addition, farmers gain opportunities such as making better and more informed decisions, using resources more effectively and making better use of the power of technology [47]. With digitalization in agriculture, it is aimed to provide technical optimization of agricultural production systems, value chains and food systems. In this way, information is provided through digitalization in sustainable agriculture, learning is improved and the crisis in the agricultural sector is improved [25]. The aim of sustainable agriculture is to maximize the net benefits 
of the society from agricultural food production and ecosystem services. This suggests increasing crop yields, increasing the efficiency of nitrogen, phosphorus and water use, improving ecological-based management practices, rational use of pesticides and antibiotics, and covering major changes in some livestock practices [56]. In addition, it provides convenience in efficient use of resources in soil preparation, planting, irrigation, care and harvesting, reducing product losses, increasing online shopping in food and providing price-quality optimization [10], [24], [50].

There are other applications that can be added to smart farming applications. These; auxiliary arrangement and orientation systems, sensor-based product detection and variable rate technologies in fertilization in field agriculture, map-based variable rate technologies in fertilization, sensorbased variable rate technologies in spraying, variable rate technologies in irrigation, variable rate technologies used in seed, isobus, robot applications, vertical agriculture and using driverless technologies. With these practices, the deficiencies in agricultural activities are eliminated and the activities become easier. For example; vertical agriculture is the process that produces food in harsh environments where suitable land cannot be used, and provides food production in vertically stacked layers. In vertical agriculture, it uses soil, soilless or aeroponic cultivation methods and uses 95 percent less water, less fertilizer and nutritional supplements, and is protected from harmful plants and animals without using pesticides [35].

Agriculture 4.0 is complemented by smart farming practices in the sector. The anaerobic system reduces waste volume and is an efficient waste treatment technology that uses natural anaerobic decomposition in biogas production. It is used in the treatment of wastes from agricultural and industrial activities [10]. On the other hand, nanotechnology shows great potential in smart agriculture. Nanoencapsulation can also improve herbicide application by providing better penetration through the introduction of nanoparticles based on nanotechnology, resistance to plant diseases, special plant growth with the help of controlled release formulations of nanoparticles in special plant growth and nutrition [13]. One of Agriculture 4.0 applications is digital slipmeter; it is expected to bring better fuel economy. Thanks to this application, optimum fuel consumption is provided. Smart agriculture, of course, provides tremendous benefits to sustainable agriculture and increases the efficiency of food production [38].

By using the Internet of Things with Agriculture 4.0, farmers can observe the crop productivity. The realized example of this application is John Deere tractors. The performance of tractors has increased with the application of the internet of objects and the estimated time of the area to be planted has been shortened [51]. An example of agriculture 4.0 applications; to combat the desert and sea in the world into food production facilities to combat the food crisis. King Abdullah University of Science and Technology (KAUST) in Arabia is at the forefront of research on desert agriculture. It works on minimizing the losses in front of plant development and makes use of smart farming practices while doing these studies [35]; [49].
Another development with Agriculture 4.0 is advanced sensors and low-cost microchips, cloud-based systems. Thanks to these practices, control in agriculture becomes easier and innovation in agriculture increases. Bioenergy productions such as vertical farming activities, installation of smart greenhouses, reduction of ecological footprint are offered to increase the value chain effectiveness, and innovative developments such as drones, robots and sharing platforms are being developed to increase product efficiency [35]; [60]; [10].

Agriculture 4.0 has applications in the world. German agricultural machinery Class firm checks the health of animals in the herd through sensors [24]. With the smart irrigation application of Bosch, olive trees were irrigated in Spain, and they determined how much water they needed and carried out irrigation activities through sensors [9].

There are two countries that are leaders in digitalization in agriculture; Israel and the Netherlands They implemented agriculture 4.0 practices more quickly than other countries. The Netherlands ranks 4th in the 2017-2018 Global Competitiveness Index [53]. The Netherlands is one of the smallest countries in Europe, it has an area of $37378 \mathrm{~km} 2$. The total exports of the Netherlands in 2018 were set at 641 805 million Euros. Agricultural production amount of the Netherlands is recorded as 89877 million Euros. The country, which is in a very good condition in terms of production despite its low agricultural area, reveals the difference in activities it has [15]. Analysis of the Netherlands by Porter model [58];

-Geographical concentration of relevant and supportive enterprises,

-Providing companies with reliable information from each other and their cooperation,

-Interaction between seed companies, agricultural companies, suppliers, logistics and educators,

-Presence of other supportive agricultural organizations

The existence of these factors in the Netherlands reveals its difference in agriculture. In the Netherlands, agricultural universities have enabled agriculture to develop and studies are conducted on the question of how to get the most output with less input. Then the Netherlands a considerably high share of the companies allocated for R\&D activities. It has a university-industry cooperation, houses successful businesses in innovation, and is a global giant in agricultural export. The Netherlands also allocates a high share of its budget to R\&D activities [23].

The Netherlands is from countries where expertise in agricultural production is declared and consists of countries with high agricultural productivity. As in the Netherlands, some areas have managed to achieve high rates of growth that increase GDP and labor productivity [2]. The Netherlands is in a good position to shape the Fourth Industrial Revolution, to design and work with high-tech preparation among individuals. The world-famous Wageningen University supports the development and awareness of farmers. [58].

Israel is one of the developed countries in high technology products and agricultural technology. It is ranked 21st in the Global Competitiveness Index List and ranked 3rd in the innovation ranking [53]. Israel is also mentioned as the country that introduced the drip irrigation system to the 
world. Israel allocates $17 \%$ of its budget to R\&D activities. Israel started smart agriculture with a smart irrigation system. It wishes to increase product yield and quality by using less water. According to the 2017 data of Israel, it exports approximately 60.5 billion dollars and it is an example of Agriculture 4.0. Israel; It has advanced technology in greenhouse, livestock and plant protection. It is in a very good condition in exporting agricultural technology to the world and constantly attaches importance to R\&D activities [49].

It is not surprising that Africa is actually enthusiastic about agriculture 4.0 as a whole. The region needs an inclusive and environmentally sustainable agricultural transformation in order to provide more food safety, improve nutrition and improve economic opportunity. It provides more efficient and small-scale farm installation, decreases food imports, tries to increase agricultural exports and carries out activities to reduce post-harvest losses. The eager steps of Africa's agricultural transformation attract attention [11]. As can be seen, the importance of correct and effective use of agricultural areas is important not only for the relevant company and country but also for the world. Agriculture is one of the most strategic issues of the world, and the waste of resources increases and the living spaces shrink.

\section{CONCLUSION}

Drones, robots, the internet of things, vertical farms, a system using artificial intelligence and renewable energy sources 4.0. or digitalization. The application of digital technologies to the agricultural sector significantly contributes to increase agricultural productivity and reliable food production.

Especially developments in information technology provide effective supply chain management and obtaining real-time data throughout the supply chain contributes to the planning of decisions. The use of this data contributes to minimizing waste, producing higher quality products and minimizing food waste. There are improvements expected from Agriculture 4.0. Technology, R\&D, intelligent growth based on information and innovation, provides sustainable growth with resource efficiency and decreasing losses, and also enables healthy growth in food safety and increased traceability and covering the supply chain, including the producer. With Agriculture 4.0, reducing waste and increasing productivity become the main tool in the agricultural sector. By means of sensors, it is ensured that soil loss is reduced and erosion is prevented. A significant increase in the number of farmers using IT technologies against climate change and environmental pollution is also a positive outcome of smart farming practices. There are natural uncertainties in the agricultural industry, introducing sensors and M2M (machine to machine) based monitoring will be an important step in preventing disasters.

In small countries (Taiwan, Israel, the Netherlands) and developing countries, the development of agricultural technologies is remarkable and the technologies that these countries use have also caused the development of the agricultural sector. In other words, it can be deduced that benefiting from Agriculture 4.0 opportunities enables countries to develop in agriculture. When we look at 2019 agricultural production data in the World.

Agriculture 4.0, which enables cooperation between different stages of the value chain and increases traceability in food safety with increased visibility in the value chain. It will lead to increases in safe food production by taking advantage of technology and ensuring efficient distribution of resources. In agriculture, the recycling of the investment is long-term and the risk area is wide and the variables are uncontrollable, making 4.0 an effective strategic tool. However, factors such as investor profile, level of countries' understanding of process, resistance of beneficiaries, and low number of agriculture 4.0 installations are seen as the biggest obstacle. With Agriculture 4.0, a smart, sustainable and healthy growth has been achieved. With the R\&D activities provided by technology, healthy growth occurs with smart growth, efficient use of resources and reduction of losses, and sustainable development and improvements in the supply chain.

Industry 4.0 has a transformative and changing effect on every sector. In the agricultural sector, breakthroughs for 4.0 developments should be taken. At the same time, countries that still produce inefficient production with traditional methods in agriculture and that have foreign dependence should give the necessary importance to Agriculture 4.0.

\section{REFERENCES}

[1] Akay, M. (2018). Endüstri 4.0 İle Akıllı Tarıma Geçiş, https://www.researchgate.net/publication/326550785, Date of access:08.03.2020

[2] Arendok, A. (2015). The development of the share of agriculture in GDP and employment, https://pdfs.semanticscholar.org/263b/17e0e3c6c9b7e7a156ec2a138fe 6955bbf91.pdf?_ga=2.138898547.1129366168.1582060039582752527.1582060039, Date of access:01.03.2020

[3] Bauernhansl, T., Krüger, J., Reinhart, G., Schuh, G. (2016). WgpStandpunkt Industrie4.0, Wissenschaftliche Gesellschaft für Produktionstechnik Wgp

[4] BCG, (2015), "Industry 4.0, The Future of Productivity and Growt in Manufacturing

[5] Beddington, J. (2010). Food security: contributions from science to a new and greener revolution," The Royal Society

[6] Beus, C. E. and Dunlap, R. E. (1994). Agricultural Paradigms and the Practice Agriculture, Rural Sociological Society, 59(4), 1994, pp. 620635 .

[7] Bhardwaj, S., Jain, L. Ve Jain, S. (2010). Cloud Computing: A Study of Infrastructure as a Service (IAAS), International Journal of Engineerging and Information Technology, Volume 2, Issue 1, pp.6063.

[8] Brettel, M., Friederichsen, N., Keller, M., and Rosenberg, M. (2014). How Virtualization, Decentralization and Network Building Change the Manufacturing Landscape: An Industry 4.0 Perspective, International Journal of Science, Engineering and Technology, 8(1): $37-44$

[9] Bosch (2020). https://www.bosch.com/stories/smart-agriculture/, Date of access:04.03.2020

[10] Chen, Y., Cheng, J.Y. and Cremar, K. S. (2008). Inhibition of anaerobic digestion process: A review, Bioresource Technology, 99 (2008) 4044 4064 .

[11] CTA (2019). The Digitalisation of African Agriculture Report 20182019, 1st Edition, June 2019.

[12] Diao, X., Hazell, P. And Thurlow, J. (2010). The Role of Agriculture in African Development, World Development Vol. 38, No. 10, pp. 1375-1383

[13] Duhan, J.S., Kumara, R., Kumara, N., Kaura, P., Nehrab, K. And Duhan, K. (2017). Nanotechnology: The new perspective in precision agriculture, Biotechnology Report 15, pp. 11-23.

[14] Dwarkani, C. Et al., (2015). Smart Farming System Using Sensors for Agricultural Task Automation, International Conference on 
Technological Innovations in ICT for Agriculture and Rural Development (TIAR 2015).

[15] European Comission (2019). Statistical Factsheet Netherlands June 2019.

[16] Foley, J. et al. (2005). Global Consequences of Land Use, Science, Vol 309, www.sciencemag.org570

[17] FAO (2012). Agricultural Outlook 2012, Achieving Sustainable Agricultural Productivity Growth

[18] FAO (2020). World Agricultural Production, https://apps.fas.usda.gov/psdonline/circulars/production.pdf, Erişim Tarihi: 18 Haziran 2020

[19] GEOSYS (2020). https://www.geosys.com.tr/tarim.php\#tarim, Date of access:03.03.2020

[20] Hansen, J.W. (1996). Is Agricultural Sustainability a Useful Concept? Agricultural Systems 50 (1996),1I7- 143 Elsevier Science Limited Printed in Great Britain

[21] Hermann, M., Pentek, T., Otto, B. (2016). Design principles for industrie 4.0 scenarios, 49th Hawaii International Conference on System Sciences, Computer Society IEEE

[22] International Trade Centre (2016). Trade Performance Index, Date of access:04.03.2020

[23] Jongebloed, P. (2010). Wageningen University and Research Centre Part of Dutch Agrofood Cluster.

[24] Kahraman, H. (2017). Endüstri 4.0 ile Birlikte Gelen Akıllı Tarım, Endüstri Platformu, Date of access:04.03.2020

[25] Klerkx, L., Jakku, E. and Labarthe, P. (2019). A Review of Social Science on Digital Agriculture, Smart Farming and Agriculture 4.0: New Contributions and a Future Research Agenda, NJAS Wageningen Journal of Life Sciences.

[26] Kılavuz, E., \& Erdem, İ. Dünyada Tarım 4.0 Uygulamaları ve Türk Tarımının Dönüşümü. Social Sciences, 14(4), pp.133-157.

[27] Lee, J., Davari Arkadani, H., Yang, S., Bagheri, B. (2015). Industrial Big Data Analytics and Cyber-Phisical Systems for Future Maintanance \& Service Innovation, Procedia CIRP, 38: pp. 3-7.

[28] Liang, Y., Lu, X. S., Zhang, D. G., \& Liang, F. (2002). The Main Content, Technical Support and Enforcement Strategy of Digital Agriculture, Geo-Spatial Information Science, 5(1), pp.68-73.

[29] Lobell, D. B. et al., (2008). Prioritizing Climate Change Adaptation Needs for Food Security in 2030, Science, Vol 319, www.sciencemag.org

[30] Lucke, D., Constantinescu, C. and Westkämper, E., (2008). Smart Factory - A Step Towards the Next Generation of Manufacturing., in (Mitsuishi, M., Ueda, K., and Kimura, F., 'eds.'): Manufacturing Systems and Technologies for the New Frontier -, Springer, London: $115-118$.

[31] Maeder, P. et al., (2002). Soil Fertility and Biodiversity in Organic Farming, Science 296, 1694 (2002), DOI: 10.1126/science.1071148

[32] McKendry, P. (2002). Energy production from biomass (part 1): overview of biomass, Bioresource Technology 83 (2002), pp. 37-46.

[33] McKinsey Company (2016). Industry 4.0: How to Navigate Digitization of the Manufacturing Sector.

[34] Monostori, L. (2014). Cyber-physical production systems: Roots, expectations and R\&D challenges. Procedia Cirp, 17, pp. 9-13.

[35] Oliver Wyman (2018). Agriculture 4.0: The Future of Farming Technology, Authors: M. D. Clercq, A. Vats and A. Biel, World Government Summit.

[36] Özdoğan, B., Gacar, A. and Aktaş, H. (2017). Digital Agriculture Practices in the Context of Agriculture 4.0, Journal of Economics, Finance and Accounting,

[37] Porter, M.E. and Heppelmann. J.E. (2016). How Smart, Connected Products Are Transforming Competition. Harv. Bus. Rev.92: 18.

[38] Pranav, P. K., Pandey, K. P., \& Tewari, V. K. (2010). Digital wheel slipmeter for agricultural $2 \mathrm{WD}$ tractors. Computers and electronics in agriculture, 73(2), 188-193.

[39] Rifkin, J. (2015). Nesnelerin İnterneti ve İşbirliği Çağı, Optimist Yayınc1lı, İstanbul.

[40] Roblek, V., Meško, M., Krapež, A. (2016). A complex view of industry 4.0, Sage Open, 6; 2: 1-11.

[41] Rojko, A. (2017). Industry 4.0 Concept: Background and Overview, International Journal of Interactive Mobile Technologies, 11 (5): pp. $77-90$.

[42] Rüßmann, M., Lorenz, M., Gerbert, P., Waldner, M., Justus, J., Engel, P., Harnisch, M. (2015). Industry 4.0: The Future of Productivity and Growth in Manufacturing Industries, Boston Consulting Group.

[43] Shamim, S., Cang, S., Yu, H. And Li, Y. (2016). Management Approaches For Industry 4. 0: A Human Resource Management Perspective
[44] Shen, S., Basist, A., \& Howard, A. (2010), Structure of a Digital Agriculture System and Agricultural Risks Due to Climate Changes, Agriculture and Agricultural Science Procedia, 1, 42-51.

[45] Siemens (2016). "Endüstri 4.0 Yolunda", http://cdn.endustri40.com/file/ab05aaa 7695b45c5a6477b6fc06f3645/End\%C3\%BCstri 4.0 Yolunda.pdf, Date of access:03.03.2020

[46] Soylu, A. (2018). "Endüstri 4.0 ve Girișimcilikte Yeni Yaklașımlar", Pamukkale Üniversitesi Sosyal Bililmler Enstitüsü Dergisi, Issue 32, Denizli, pp.43-57.

[47] Sun, S., Zhang, C., Li, X., Zhou, T., Wang, Y., Wu, P., \& Cai, H (2017). Sensitivity of crop water productivity to the variation of agricultural and climatic factors: A study of Hetao irrigation district, China. Journal of Cleaner Production, 142, 2562-2569

[48] Strandhagen, J.W., Alfnes, E., Strandhagen, J.O., Vallandingham, L.R. (2017). The fit of Industry 4.0 applications in manufacturing logistics: a multiple case study. Adv. Manuf. 5:344-358.

[49] TABİT (2019). http://www.tabit.com.tr/coskun-yildirim-tv35yayininda/, Date of access:09.03.2020

[50] T.C. Ticaret Bakanlığı (2017). www.ticaretbakanlığı.gov.tr, (Date of access:01.03.2020).

[51] Tektaş, A. (2018). Tarım ve Teknoloji Genel Eğilimleri Sunumu, 8. Tarım, Gıda ve Soğuk Zincir Lojistiği Sempozyumu.

[52] The Economic Times (2015). China Sets Up First Unmanned Factory; All Processes Are Operated By Robots. [Available online at: https://economictimes.indiatimes.com/news/international/business/chi na-sets-up-first-unmanned-factory-all-processes-are-operated-byrobots/articleshow/48238331.cms?utm campaign=DonanimHaber\&ut $\mathrm{m}$ medium=referral\&utm source.

[53] The Global Competitiveness Report (2019). The Global Competitiveness Report, World Economic Forum, Date of access:02.03.2020

[54] Tilman, D., Cassman, K., Matson, P. et al. Agricultural sustainability and intensive production practices. Nature 418, 671-677 (2002).

[55] UN (2015). Transforming Our World: The 2030 Agenda for Sustainable Development Report.

[56] USB (2017). The Future of the Western Cape Agricultural Sector in the Context of the 4th Industrial Revolution.

[57] Villalobos, J. V., Soto-Silva, W., Gonzalez-Araya, M.C. and Ramiraz, R.G. (2019). Resarch Directions in Technology Development to Support Real-Time Decisions of Fresh Produce Logistics: A Rewiev and Research Agenda, Computers and Electronics in Agriculture 167 (2019) 105092.

[58] Vossenaar, F. (2018). Agriculture in Netherlands: The drive for Circularity.

[59] Vörösmarty, C.J. et al. (2000). Global Water Resources: Vulnerability from Climate Change and Population Growth, Science, www.sciencemag.org284.

[60] Wang, S., Wan, J., Zhang, D., Li, D. and Zhang, C. (2016). Towards smart factory for Industry 4.0: Self- organized Multi-Agent System With Big Data Based Feedback and Coordination, Computer Networks, Vol 101, pp. 158-168.

[61] Weltzen, C. (2016). Digital agriculture - or why agriculture 4.0 still offers only modest returns, Landtechnık, 71(2), 2016, 66-68.

[62] WTO (2019). World Trade Organization World Trade Statistical Review2019,https://www.wto.org/english/res_e/statis_e/wts2019 e/w ts19_toc_e.htm, Date of access: 04.03.2020

[63] Wolfert, S., Ge L., Verdouw, V. ve Bogaardt, M., 2016. Big Data in Smart Farming - A review, Agricultural Systems 153 (2017) pp.69-80.

[64] World Bank (2020). http://datatopics.worldbank.org/worlddevelopment-indicators/, Date of access 05.03.2020

[65] Zhou, K., Liu, T., \& Zhou, L. (2015). Industry 4.0: Towards future industrial opportunities and challenges. In 2015 12th International conference on fuzzy systems and knowledge discovery (FSKD) (pp. 2147-2152).

Mustafa Atilla Arıcıoğlu completed his undergraduate education at Dokuz Eylul University, Department of Business Administration. He completed his postgraduate and doctorate in Management and Organization at Selçuk University. He became an Associate Professor in Strategy and Management. He worked at Selcuk University, Konya Food and Agriculture University, Necmettin Erbakan University, Faculty of Engineering and Faculty of Political Sciences. Currently, Erbakan University, Faculty of Political Sciences, Department of Business Administration, Ph.Dr. works as. 
Aylin Yilmaz graduated from the business administration department of the Faculty of Economics and Administrative Sciences in Selcuk University in 2013. Then Necmettin Erbakan University completed its MA in business administration in 2017. Contınuing to doctoral education in Necmettın Erbakan Unıversity. She works as a lecturer at Karamanoğlu Mehmetbey University.

Nadiye Gülnar, was born on November 22, 1984 in Tehran. She started primary school in Athens and secondary school in Bonn. She graduated from Tehran International School in 2003. She started her undergraduate education in 2003 at ECO College of Insurance/Tehran, an completed in the Business Administration Department of the Faculty of Political Sciences of Ankara University in 2009. She speaks English fluently, as well as moderate Persian, German and Greek. She started Necmettin Erbakan University, International Relations U.S.A., South Asian Studies and International Relations Department English Master's program September 2014, continues the thesis stage. At the same time, she is still continuing her master'sprogram in Konya Food and Agriculture University, Institute of Social Sciences, International Trade and Business English Master Program. Between April 2016 and March 2019, she worked as an Entrepreneurship Center and International Collaboration Specialist at Innopark Konya Technology Development Zone Manager Inc. and as a project manager within the scope of TÜBITAK Innovation and Entrepreneurship Support Program. Since April 2019, she has been working as a Project Support Specialist at Konya Food and Agriculture University Technology

Transfer Office. 